Journal of Social Sciences 7 (3): 462-465, 2011

ISSN 1549-3652

(C) 2011 Science Publications

\title{
Bamboo Fabric: A Study of Using Thick Bamboo Fiber for Producing and Developing Thai Textiles
}

\author{
Sisika Wannajun, Songkoon Chantachon and Sasta Laoakka \\ The Research Institute of Northeast Art and Culture, \\ Mahasarakham University, Mueang District, Mahasarakham 44000, Thailand
}

\begin{abstract}
Problem statement: The way of life of Thai people has involved utensils or things which made of bamboo since the ancient time. Rural Thai people use bamboo for building houses, making handicrafts, basketwork and household utensils. At present, thick bamboo is used and developed to many new products especially the textile products. Three purposes of this research were these: (1) to investigate the background of Thai textile production, (2) to investigate current situations and difficulties of Thai textile production and (3) to investigate the use of thick bamboo fiber for producing and developing Thai textiles. Approach: Research processes divided into 2 phases were these: the first phase was a quantitative experimental research type of bamboo fibers, the second phase was an application of the results of the first phase research to the phase was a qualitative research. The instruments for collecting data for the second phase research were a survey, an interview, a focus group interview and a workshop. Research areas were Ban Lung Pra Du, Amphoe Huay Talang, Nakhon Ratchasima Province, Amphoe Chonnaabot, Khon Kaen Province and Ban Tha Khon Yang, Amphoe Kantharawichai, Maha Sarakham Province. A sample of 200 people consisted of 20 key informants, 100 casual informants and 100 general informants. Quantitative data were analyzed by descriptive statistics such as percentage, mean and standard deviation. Qualitative data were analyzed by means of an interpretation within the concepts and theories involved. Research results were presented by means of a descriptive analysis. Results: (1) in terms of the background of Thai textile production, it revealed that there were human beings lived in Thailand about 7,000-8,000 years ago and they could use natural fiber from plants and animals for weaving. The evidence which confirmed this truth was the excavation of historical objects in prehistorically sites in Thailand and there were remnants clung to or filled in them. (2) In terms of current situations and the difficulties of Thai textile production, it reveals that an economic and a political change at both local and international levels is the indirect factor but the direct factor which affects Thai textile production is the pollutants resulted from all processes of a supply chain such as a process of fiber production, a process of fiber spinning, a process of fiber weaving, a process of fabric dyeing, a process of fabric completion and a process of making clothes for wearing or decorating. (3) In terms of the use of thick bamboo fiber for producing and developing Thai textiles, it revealed that using thick bamboo fiber gave us a lot of benefits; for example reducing pollutants were harmful to environment, reducing the importation of weaving materials and encouraging economic and income growth of community. Conclusion/Recommendation: The persons involved should apply these research results to develop their textile production and to search for the ways to use thick bamboo fiber for other advanced purposes.
\end{abstract}

Key words: Bamboo fabric, thick bamboo fiber, Thai textiles, supply, chain

\section{INTRODUCTION}

The background of fiber for weaving and textiles began from the excavation of the things involved textile production such as old pieces of a loom, old spinning wheels, old spools, old bobbins and remnants in the lakes in Switzerland and the graves in Egypt. This confirms that humans could produce quality textiles more than thousand years ago. Prehistorically people used leather or leaves for protecting their bodies from harmful weather and in the latter period people used apparel as social ranking or social status indications and

Corresponding Author: Sisika Wannajun, Research Institute of Northeast Art and Culture, Mahasarakham University, Mueang District, Mahasarakham 44000, Thailand 
as decorations but a weakness of using leather as apparel was its fur became a solid layer because of humidity, heat and pressure when it was worn for a long time. Thus, it is an original point of the invention of fur clothes and artificial fur clothes. Cotton spinning is a adapted from a process of rope-making and cloth weaving is imitated from a process of branch and leaf weaving for building a shelter of ancient people (Wuttakun, 1996).

The development of Thai textiles divided into 8 periods as follows: (a) The period of Lanna kingdom, it was about the $18^{\text {th }}$ Buddhist century that ethnic Thai groups established their kingdom in the north of Thailand such as Chiang Mai, Phayao, Phrae, Nan, Lampang, Lanphun and Mae Hong Son. Cloth trade diffused widely both in the kingdom and neighbouring kingdoms in that period. (2) The period of Sukhothai kingdom, it was the Thai kingdom settled in the upper of central part of Thailand. Many types of clothes were woven, cloth weaving classified into 2 purposes were cloth weaving by general people for household uses and cloth weaving by royal artisans for the royal uses. Furthermore, there were many types of clothes imported from other countries; for example China, India and Persia. (3) The period of Ayuthaya kingdom, it was a period which cloth trade was the most prosperous of all kingdoms. It can say that Ayuthaya was a great center of cloth trade in that time. Clothes were imported from other countries for the royal and public uses more than the period of Sukhothai kingdom, especially silk and rayon from China, printed clothes from India, fine texture clothes from Europe, silk brocade and carpets from Persia (4) The period of Thonburi Kingdom and early Rattana Kosin Kingdom, it was the period of war and reconstruction. According to evidence, it revealed that weavers were conscripted from Saiburi (Kedah) for training native people in Songkhla and Nakhon $\mathrm{Si}$ Thammarat on brocade weaving and afterwards this type of cloth has been famous up to now. (5) The rign of King Rama III, dark blue clothes, gold brocade, twill and other fine texture clothes were used for the royal family but clothes for general people were declined in quality, colours and patterns. (6) The reign of King Rama V, there was a change of clothes for the nobility and government officials from wearing old traditional hip wrapper into dark-blue hip wrapper and the king granted them new uniforms according to official positions by using colours of rayon for indicating each ministry. Men's and women's clothing was rather developed to a European style in that period. (7) The reign of King Rama VIII, royal clothing changed from using expensive cloth with silver and gold thread to simple cloth. Silk cloth was still popular for making clothes. (8) The reign of King Rama IX, His Majesty King Bhumibol Adulyadej and Her Majesty Queen Sirikit are interested in local cloth weaving so their Majesties the King and Queen encourage local people to develop their cloth weaving in terms of a wide variety of designs, patterns and colours. This development causes both Thais and foreigners widely appreciate Thai cloth (Thai Textile, 2010).

All mentioned above cause the researchers are interested in researching about the use of thick bamboo fiber for producing and developing Thai textiles in order to discover technological innovations in Thai textile production, increase new choice for customers and reinforce international competitive potential for Thai textile industries. Purposes and objective: Three purposes of this research were these: (1) to investigate the background of Thai textile production, (2) to investigate current situations and difficulties of Thai textile production and (3) to investigate the use of thick bamboo fiber for producing and developing Thai textiles.

\section{MATERIALS AND METHODS}

Population and sample: A sample of 220 people consisted of 20 key informants, 100 casual informants and 100 general informants.

Instruments: Research instruments were an observation an interview, a focus group discussion and a workshop.

Data analysis: The data were analyzed by means of an intepretion according to the concepts and theories involved

Result presentation: A descriptive analysis was used for presenting the results.

\section{RESULTS}

Research results were as follows: (1) In terms of the background of Thai textile production, it revealed that according to archaeological evidence founded in Thailand, the people who lived in Thailand used natural fiber from plants and animals for weaving clothes about 7,000-8,000 years ago. For written evidence, it reveals that Thai textile production for a commercial purpose began in the period of Lanna kingdom; ethnic Thai group established their first kingdom in the north of Thailand and began to produce textiles so Thai textile production for a commercial purpose has originated 


\section{J. Social Sci., 7 (3): 462-465, 2011}

since then. (2) In terms of current situations and difficulties of Thai textile production, it reveals that there are many factors which affect Thai textile production. An overview of the difficulty of Thai textile production is an economic and a political change at both local and international levels. An important difficulty which directly affects Thai textile production is all of production processes always leave pollutants to environment. (3) In terms of the use of thick bamboo fiber for producing and developing Thai textile, it revealed that fabric made of thick bamboo fiber had 7 benefits were these: (1) the benefit of its natural soft and comfortable wear properties, (2) the benefit of its non-irritating properties, (3) the benefit of its temperate adjustable properties, (4) the benefit of its humidabsorbed and ventilated properties, (5) the benefit of its anti-bacterial and stinking properties, (6) the benefit of its crease recoverable properties and (7) the benefit its ultraviolet resistant properties. Moreover, it reduced the import of weaving materials, reduced a lack of weaving materials and reduced pollutants resulted from production processes.

\section{DISSCUSSION}

In terms of the background of Thai textile production, it revealed that according to archaeological evidence found in Thailand, the people who lived in Thailand used natural fiber from plants and animals for weaving clothes about 7,000-8,000 years ago. Written evidence pointed out that Thai textile production for a commercial purpose began in the period of Lanna kingdom, the first kingdom that Thai people formed their group in the north of Thailand and it can say that Thai textile production has begun since then. This is consistent with research result of Kartiwa (1987) which studied about ancient Indonesian fabrics, it revealed that Indonesian fabrics made of several fibers; for example cotton, banana, pineapple, palm and orchid since the Republic of Indonesia located in the tropical Zone and was rich in fibers from plants. Moreover, it is consistent with research result of Aranyanak (1991) which studied about fabrics from archaeological sites in Thailand, it revealed that cloth weaving technology was developed from rope-making and the majority of ropes found in archaeological sites made of grass, vines, rushes, reeds and bamboo which were available local plants.

In terms of current situations and difficulties of Thai textile production, it reveals that an overview of difficulty of Thai textile production is an economic and a political change at both local and international levels. A factor which directly affects Thai textile production is a difficulty of pollutants resulted from all production process such as a process of fiber production, fiber spinning, fiber weaving, fabric dyeing, fabric completion and making clothes for wearing or decorating. This is consistent with research result of Phanitchaphan (2005) which studied about developing of medical textile products by using nano technology, it revealed that using nano technoly for producing gowns was friendly to environment and users. Moreover, gowns made of $100 \%$ of cotton and enameled with nano particle such as zine oxide, titanium dioxide, silver nano particle, antimicrobial, durable medical protective garment, disposal medical protective garment had anti-bacterial properties.

In terms of the use of thick bamboo fiber for producing and developing Thai textiles, it revealed that thick bamboo had large poles, it was easy and rapid to propagate so its fiber suited to make textile more than other fibers. After testing properties of several bamboo fibers in the laboratory, it revealed that thick bamboo fiber had a lot of positive properties more than the others. The researchers selected thick bamboo fiber for producing $100 \%$ bamboo fiber clothes and mixed bamboo fiber clothes; for example cotton-bamboo fiber clothes, hemp-bamboo fiber clothes, silk-bamboo fiber clothes and the others. Thick bamboo fiber clothes which were produced and developed had 7 positive properties were these: (1) natural soft properties which provided comfortable wear for users, (2) non-irritating properties which was good for user skin, (3) temperate adjustable properties which made users cool when the weather was hot and warm when the weather was cold, (4) humid-absorbed and ventilated properties which protected user from skin diseases and harmful temperatures, (5) anti-bacterial and stinking properties, bamboo kun prevented thick bamboo fiber clothes from bacterial cultivating, (6) crease recoverable properties which helped users in terms of no ironing and (7) UVresistant properties which protected users from harmful UV.

\section{CONCLUSION}

These research results point out that Thai textile production has begun since 7,000-8,000 years by deducing from the ages of remnants which were clung to or filled in historical objects excavated from prehistorically sites in Thailand. Thai textile production has been affected by internal and external factors. An overview of current situation is the difficulty within a supply chain such as a lack of weaving materials and pollutants resulted from production processes. Using 
thick bamboo fiber for producing and developing Thai textiles gives us a lot of benefits; for example reducing imported weaving materials, reducing a lack of weaving materials, reducing pollutants resulted from production processes. Moreover, thick-bamboo clothing gives healthy properties for users and friendly properties to environment. The persons who are interested or involved in textile production can apply the results of this research to develop textile production of their firms.

\section{ACKNOWLEDGEMENT}

First of all, thanks to the Research Institute of Northeastern Art and Culture Mahasarakham University which has given us remarkable freedom to study on this topic. Allmost all of the content of this dissertation was gathered from field study so we would like to express our sincere appreciation for all informants in Nakhon Ratchasima, Khon Kaen and Maha Sarakham and all of the support provided.

\section{REFERENCES}

Aranyanak, J., 1991. Archaeological Textiles in Thailand. 1st Edn., Samaphan, Bangkok, ISBN: 9744172061, pp: 151.

Kartiwa, S., 1987. Tenun Ikat Indonesian Ikats. 1st Edn., Jakarta, Djambatan, ISBN: 10: 9794280240 , pp: 97.

Phanitchaphan, S. 2005. Developing of Medical Textile Products by Using Nano Technology. The Institute of Textile Development, Bangkok. http://www.thaitextile.org/th/textile_intel/documen t/thtidoc/06technology/Present_Seminar_29_3_49/ MedicalTextiles_Nanotechnology.ppt

Thai Textile, 2010. The Periods of Thai Textiles. http://www.thaitextilemuseum.com

Wuttakun, W., 1996. Fabrics and Ways of Life of Thai People. Office of the National Culture Commission, $\quad 79$ : http://www.thaistudy.chula.ac.th/m13-05detail.php?id=8886 